\title{
Information, Accountability and Perceptions of Public Sector Program Success: A Conjoint Experiment Among Bureaucrats in Africa
}

\author{
Adam Harris \\ University College London \\ Brigitte Seim \\ University of North Carolina, Chapel \\ Hill \\ Rachel Sigman ${ }^{\dagger}$ \\ Naval Postgraduate School
}

Motivation Whether public sector organizations implement programs successfully is a key concern of development scholars and practitioners across the world. While many studies purport a link between social accountability and public sector performance, this relationship has been difficult to study empirically.

Purpose This paper examines whether bureaucrats anticipate that public sector programs with information-sharing mechanisms, including visibility, transparency and collaboration, will be successful in terms of effectiveness and limiting corruption.

Approach The paper uses a conjoint survey experiment administered to and Methods thousands of bureaucrats across three African countries: Ghana, Malawi and Uganda. By asking bureaucrats - those with insider knowledge of government program operations - about two hypothetical programs with randomly assigned characteristics, we examine whether bureaucrats associate opportunities for monitoring by citizens and civil society groups with the success of public sector programs.

Findings Across diverse country and organisational contexts, bureaucrats consistently attribute high probabilities of success to programs that are visible to the public, transparent in their 
implementation, and open to collaboration with civil society. Moreover, the inclusion of any one of these information-sharing mechanisms can independently increase their perceived likelihood of success. The findings hold across institutional contexts and diverse subgroups of bureaucrats surveyed.

Policy To promote success in the implementation of public sector Impli- development programs, officials should look for ways to increase cations the visibility of their programs, set requirements for frequent public updates on program progress, and build in opportunities for outside groups to collaborate.

Keywords: Public sector, accountability, transparency, monitoring, Africa Word Count: 7,782 


\section{Introduction}

Despite an abundance of research and funding devoted to improving and reforming public sector institutions in the developing world, their success in implementing programs remains mixed and, in many cases, falls short of what is desired by citizens or donors. Researchers and practitioners have identified a large number of factors that may contribute to more successful programs but, as Merilee Grindle writes, there remain "a host of questions about what needs to be done, when it needs to be done, and how it needs to be done"(Grindle, 2004, 525-526). Except, perhaps, in focusing greater attention to the range of actors and incentives that affect the success of public sector programs (Brinkerhoff and Brinkerhoff, 2015; Levy, 2014; Fritz, Levy and Ort, 2014), the key drivers of success in program implementation throughout the developing world are still not thoroughly understood. If anything, this shift in focus to actors and incentives has even further expanded the range of variables theorised to affect the implementation of public programs (Grindle, 2017). ${ }^{1}$

One important strand in the literature on public sector performance concerns the concept of social accountability: a range of mechanisms that generate incentives for politicians and bureaucrats to implement public sector programs successfully. This perspective emphasises in particular the ways that engagement by citizens and groups motivates public servants to improve performance (Batley, McCourt and Mcloughlin, 2012; Wetterberg, Hertz and Brinkerhoff, 2018). Incorporating mechanisms of social accountability into a wide variety of administrative, service delivery and reform programs has become central to the governance agenda in many developing countries (Andrews, Woolcock and Pritchett, 2017; Barma, Huybens and Viñuela, 2014).

In some cases, however, this focus on social accountability has been met with

\footnotetext{
1 Throughout this article we refer to public sector programs as an umbrella term that includes a wide range of development-oriented programs including service delivery, institutional reform and regulation.
} 
skepticism. Studies reveal, for example, that citizen pressure alone may be insufficient to meaningfully improve public sector programs (Fox, 2015; Hossain, 2010), or that the involvement of certain groups or citizens may generate perverse forms of accountability (Stokes, 2005). Such findings not only raise questions about the importance of social accountability as an ingredient for the success of development programs, but also about the specific types of accountability that matter most.

This paper investigates the relationship between social accountability mechanisms and the anticipated success of public sector programs using a conjoint experiment embedded in a survey of bureaucrats in Ghana, Malawi and Uganda. Relying on bureaucrats' insider perceptions of the drivers of program success provides an important empirical addition to understanding public sector performance. Bureaucrats are particularly well positioned to evaluate the determinants of program success, since they see both the workings and outcomes of public programs on a day-to-day basis.

Whereas past studies focus on one aspect of success such as program completion or corruption, our experimental design allows us to test multiple dimensions of success at the same time. Moreover, By randomly assigning different attributes to hypothetical programs that respondents would plausibly undertake in their jobs, the survey experiment assesses, in a novel way, whether bureaucrats associate accountability mechanisms - informationsharing with actors outside of government that could lead to greater demands for accountability - to affect program success. Moreover, the conjoint experiment allows us to examine simultaneously different dimensions of program success including effectiveness, corruption and efficiency. Given its implementation in three countries, the study also identifies which types of accountability mechanisms maintain their relative importance across varying contexts.

The findings unequivocally suggest that bureaucrats expect programs to be successful when there are opportunities for information sharing including, in particular, visible outputs, transparent implementation processes, and collaboration with civil society 
organisations (CSOs). Moreover, the inclusion of any one of these information-sharing attributes can independently increase the likelihood of perceived success. The findings hold across all measured dimensions of success: effectiveness, reduced corruption risk and equitable distribution of goods and services. They also hold across institutional contexts and diverse subgroups of bureaucrats surveyed.

These findings provide clear guidance from bureaucrats for reducing corruption and maximising effectiveness of government programs. For example, the bureaucrats in our study expect that programs would be more successful if officials look for ways to increase the visibility of their programs, set requirements for frequent public updates on program progress, and build in opportunities for civil society groups to collaborate in the implementation of the program. All of these mechanisms improve information sharing, which facilitates greater accountability. Importantly, citizens have a key role to play in ensuring program success; empowering them to do so may be challenging, but the evidence from the bureaucrats in our study suggests that citizen awareness is of the utmost importance.

In addition to affirming the importance of social accountability for the success or failure of public sector programs, the findings make a number of core contributions to this literature. First, building on past research, we distinguish between distinct opportunities for social accountability including the provision of information through visible outputs and transparent implementation processes, as well as the direct engagement of outside groups such as civil society (Muchadenyika, 2017). While engagement with outside groups has the most consistent positive effects on program success, we find that both visibility and transparency can also significantly increase the likelihood of success. Thus, while the literature on transparency often points out that information in and of itself is not enough to ensure accountability (Fox, 2015; Cucciniello, Porumbescu and Grimmelikhuijsen, 2017; Bauhr and Grimes, 2014; Lindstedt and Naurin, 2010; Peisakhin and Pinto, 2010), we find that bureaucrats do in fact see information provision as a necessary condition for public sector program success, even if it is not 
independently sufficient.

In the next section we discuss the ways that social accountability is theorised to increase the success of public sector programs. We then describe our country cases and research design, followed by a presentation of the results. We conclude with a brief discussion of the findings and their implications for future studies of social accountability and public sector performance.

\section{Information Sharing, Accountability and Public Sector Programs}

Whereas problems in the implementation of public sector programs were once seen primarily in terms of deficiencies in technical capacity or internal management structures, there is now greater attention to the social accountability relationships that affect program success (Andrews, Woolcock and Pritchett, 2017). Defined as the way individuals or organisations hold governments responsible for their decisions and sanction officials if necessary (Ebrahim, 2003; Ackerman, 2005), accountability relationships may work in several ways to improve program outcomes. They may, for example, incentivise public sector personnel to improve performance (Batley, McCourt and Mcloughlin, 2012), help to deliver mandates and generate outside support for programs (Barma, Huybens and Viñuela, 2014, 22), constrain bureaucrats

from engaging in corrupt acts (Deininger and Mpuga, 2005; Grimes, 2013), or promote information sharing in ways that that enable greater responsiveness to citizen preferences (Haque, 2000).

At its core, accountability reflects a principal-agent problem. After having transferred decision-making capacity to government, citizens and civil society organisations may request information about policies and explanations of decisions or seek to monitor the government's actions. If government agents fail to provide adequate information or justification, sanctions may follow (Andrews, Woolcock and Pritchett, 2017). Accountability therefore typically involves some combination of information exchange 
through monitoring and, in some cases, direct participation by citizens or groups.

We consider cases when those administering public sector programs supply opportunities for accountability. We focus, in particular, on three attributes of programs that are central to the relationship between accountability and performance because they provide greater information to citizens: 1) implementing programs with visible outputs (visibility), 2) providing information about the program and implementation process (transparency), and 3) collaborating with outside groups (collaboration).

\subsection{Visibility}

Visibility reflects whether or not the public can view program outputs. Citizens or groups can more easily hold the government to account when the program is more visible because of the ease of accessing information and monitoring outputs. For example, programs with readily visible outputs such as the development of a new school are more easily monitored than an education improvement program (Besley and Ghatak, 2003). In short, programs with visible outputs passively convey information to citizens or groups about public sector performance.

Observation by citizens or groups may enhance accountability and program success in several ways. For example, observation may give rise to satisfaction or displeasure on the part of observers. This feedback can, in turn, prompt improvement in the implementation of the program.

Visibility may also lead to greater success in programs because it may help to create supportive constituencies (Wilson, 1989). Supportive constituencies can be particularly important in the implementation of reform programs where some groups or influential individuals may try to block progress. Early, visible 'wins' that generate support for the overall program are therefore essential to sustain program implementation and bring it to completion (Barma, Huybens and Viñuela, 2014; Andrews, 2013).

Holland (2017) also argues that using individuals' experiences with service provision helps to focus discussions between citizens and government. As services become more 
accessible, this can mean critical benefits for marginalised groups, leading to a virtuous cycle of empowerment and ability to participate in the future (Kilby, 2006; Holland, 2017). Visibility has also been linked to program success through the mechanism of credit claiming. Visibility heightens the public profile of the program, motivating involved bureaucrats to work towards success, temper corruption, and implement the program more effectively, so

they can claim credit for, or at least be associated with, a successful program (Batley and Harris, 2014; Batley and Mcloughlin, 2015). More specifically, visibility makes it appealing for bureaucrats to forgo the benefits of corruption and program capture for the reputational benefits that this positive association will provide.

While program visibility is to a large extent dictated by the type of program or policy involved (Lowi, 1964), there are an increasing number of tools for bureaucrats to enhance opportunities to make their programs more visible to the public. The constant development of information and communications technology has enabled the sharing of experiences, which can magnify the role of visibility for accountability. For example, Pakistan tried to harness the power of visibility, utilising an SMS platform to gather information on bribes from people who used public services. As of November 2014, 110,000 citizens had reported corruption issues out of the 500,000 who responded to the SMS, and authorities took 3,600 actions against complaints (Marin, 2016; Verdenicci and Hough, 2015).

Given this discussion, we expect public sector programs with greater visibility will see higher rates of success. When citizens and groups can more easily view progress of and outcomes from a program, they can then take actions that hold the government accountable for any number of program problems such as incomplete implementation, resource diversion or political interference.

\subsection{Transparency}

Governments also provide opportunities for accountability by being more transparent regarding their actions (or inaction). In this sense, governments may provide information 
to the public in ways that that allow for action or monitoring (Florini, 2007). Transparency makes program success more likely by reducing a "natural asymmetry of information" between governments and citizens (Stiglitz, 2002). ${ }^{2}$ Arming citizens with information helps citizens or groups to hold government accountable. Joshi (2017) and Chene (2011) agree that an informed and mobilised populace is a prerequisite for effective citizen oversight and accountability. Even if national-level advocacy is what succeeds at improving or replacing a policy, citizens must monitor whether these victories are fully implemented because they are the intended beneficiaries (Fox, 2016).

Transparency is also seen as an important tool for the prevention of corruption (Florini, 2007). Transparency makes corruption less likely because it provides information that may help to expose wrongdoing to accountability actors, or may be used directly by official bodies - courts or oversight bodies - that sanction actors engaging in corruption (Fox, 2007). Transparency may, therefore, both empower accountability actors and act as a deterrent for agents looking to profit from their positions.

Transparency can be increased through a number of mechanisms including: publication of information on resource flows freedom of information laws (Berliner, 2014; Sugiyama, 2016), and participatory audits that allow citizens to participate in budget management (Sugiyama, 2016; Carlitz, 2010; Abers, 2000; Baiocchi, 2005).

Transparency and visibility are certainly related, but we draw several distinctions in our conceptualisation of them. Visibility captures whether or not the public can view program outputs in their day-to-day life, whereas program transparency captures whether or not the public can access information about program processes. In this conceptualisation, visibility requires only passive involvement by the public, relying on the non-excludable good of observation. On the other hand, transparency requires active involvement by the public, who at a minimum must process information. Regardless of the

\footnotetext{
2 For an overview of theorised effects of transparency on government performance, see Cucciniello, Porumbescu and Grimmelikhuijsen (2017).
} 
level of transparency, it pertains to something excludable - information - that can be limited by those in power or provided only to certain members of the public rather than everyone.

We therefore expect programs with greater transparency to have higher rates of success. When the government provides more information regarding progress of and outcomes from a public sector program, citizens can then hold the government accountable when they fail to provide what they promised or corruption becomes evident.

\subsection{Collaboration}

Collaboration with citizens or civil society groups in public sector programs provides another type of opportunity for accountability. Not only does collaboration offer potential for enhanced information-sharing mechanisms that are key to visibility and transparency, but collaboration also facilitates repeated two-way exchanges of information whereby information from principals (citizens or groups) can be conveyed directly to agents.

CSOs are particularly well positioned to demand accountability because of their greater organisational capacity, influence and resources compared to individuals (Sugiyama, 2016). Without organisation, citizens struggle to influence the policy process above their local government, and many decisions and acts of corruption occur above that level (Fox, 2015; Fox and Halloran, 2016; Brett, 2003; Fox and Aceron, 2016). Their ability to facilitate collective action is likely to make monitoring opportunities more valuable (Bauhr and Grimes, 2014), and some have even argued that transparency is only useful when combined with vehicles of collective actions (Fox, 2015; Cucciniello, Porumbescu and Grimmelikhuijsen, 2017). As such, collaboration with civil society organisations enables citizens to better use government information and more effectively work together to hold the government accountable.

CSOs have a number of avenues through which they can influence accountability and program success. First, they can help citizens access and decipher complex government 
documents (Sugiyama, 2016; Brockmyer and Fox, 2015; Ackerman, 2005; Carlitz, 2010; Hickey and King, 2016). Second, CSOs amplify the collective voice of individuals. When CSOs draw attention to misdeeds of bureaucrats and spread information, monitoring has been found to be more effective (Sugiyama, 2016; Lindberg, Luehrmann and Mechkova, 2017). Third, they can aggregate demands from citizens and ensure they are coherent (Ackerman, 2005). This suggests that when CSOs collaborate with government in program development, they can present individuals voices in a more focused manner.

Collaboration between government and CSOs in the implementation of public sector programs has been found to lead to success in diverse contexts. In one study of World Bank projects, for example, increasing the number of non-state actors participating in the project leads to overall improvements in project outcomes (Shin, Kim and Sohn, 2017). Another study finds CSO collaboration as having a positive impact in programs seeking to promote livestock husbandry, environmental protections, and local small businesses in Africa (Brinkerhoff, 1999). In the case of a program to reform natural resource management policies, government agencies in Zimbabwe had to work with local business organisations to ensure that the new policies regarding animal regulations also came with guarantees and provisions for employment, training and higher fees accruing to community members. This ensured that the new environmental regulations did not have adverse impacts on the local economy (Brinkerhoff, 1999). And finally, CSO collaboration improved the ability of Ugandan hospitals to provide HIV/AIDS services, but such improves were lost once the collaboration ended suggesting the need for longer-term collaborations (Bukenya, 2018).

The accountability-serving roles of CSOs are by no means automatic. CSOs may be co-opted by the state in ways that undermine accountability (e.g., Tripp 2001, Gyimah-Boadi 2004, Lewis 1992), collaborations may be structured in a top-down manner that limits agency on the part of the CSOs (Zadek and Radovich 2006), or CSOs may represent the values and 
ideas of international actors rather than citizens themselves (Keck and Sikkink 1998, Easterly 2006) in ways that do not meaningfully engage contentious political issues (Fowler and Biekart 2013). Moreover, public sector employees may have concerns about partnerships with CSOs, such as in terms of their organisational capacity, the potential quality of the partnership, or competition over influence and resources (Gazley and Brudney 2007). Despite these potential pitfalls in CSO collaboration, the preponderance of evidence suggests that partnerships are likely to enhance responsiveness and accountability. As Jennifer Brass explains, "NGO-government collaboration is part of a slow-moving, long-term turn toward increasing accountability and participation in the governance of service provision ... An NGO worker agreed, saying that civil servants `are now more proactive. They really try to do their jobs since [NGOs became more involved]'”(2014, 108)

We therefore expect public sector programs that enjoy greater collaboration with CSOs will see higher rates of success. When CSOs can more effectively monitor government actions by being directly involved in a program, CSOs can hold the government accountable when they fail to effectively execute the program.

\subsection{Defining Program Success}

The growing literature on accountability suggests, by and large, that public sector programs involving visibility, transparency and collaboration are more likely to be successful than those that do not involve such attributes. But, how should program success be defined and what are the dimensions of program success?

Success may be viewed in terms of efficiency, effectiveness (Ika, Diallo and Thuillier, 2010) and, in some cases, equity (Cameron, 2004). With respect to efficiency, there is a large focus on corruption, which is particularly relevant in our country contexts (Reinikka and Svensson, 2005; Tambulasi, 2009; Owusu, 2017). Corruption in its various forms dilutes the potential 
positive impacts of public sector economic programs (Hydén, 1983; Rose-Ackerman, 1999; Besley, 2006). In terms of effectiveness, programs may simply fail to achieve their intended goals for any number of reasons that are not necessarily related to corruption. In his study of infrastructure projects in Ghana, for example, Williams (2017) argues that managers have incentives to start new projects before completing those in progress. Third, success may mean that the program reaches those most in need. This concern about equity recognises that politicians may seek to use public programs to target supportive voters or co-ethnics rather than those most in need of the public goods or services mandated by the program (Stokes et al., 2013; Golden and Min, 2013)

We also seek to define success broadly in this way (efficiency, effectiveness, and equity) because of the broad scope of our research. As described in more detail in the next section, we draw on the perceptions of bureaucrats from a wide variety of institutional contexts. While equity may be more important in some contexts, such as in organisations that focus on the delivery of services, effectiveness may be a more important outcome in, for example, the implementation of a reform program. Therefore, a broader definition that takes into account more than one dimension of success is ideal.

Measuring success has proven to be both difficult and contested. In fact, some contend, and we agree, that success is subjective and relying on perceived success is likely the most reliable approach (Baccarini, 1999; Baker, Murphy and Fisher, 1988). Importantly, what is perceived as 'success' varies by stakeholder (Lim and Mohamed, 1999). In this study, we consider bureaucrats' perceptions of success. Bureaucrats are important stakeholders who provide a unique perspective on success given their intimate knowledge of and experience with public sector programs. That said, we note that our findings should not be interpreted as identifying the factors that definitively lead to program success, but rather as identifying the factors that bureaucrats associate with program success. 


\section{Research Design}

We examine the determinants of perceived program success using a conjoint survey experiment embedded in a face-to-face survey of 4,451 bureaucrats in Ghana $(1,641)$, Malawi (1,273), and Uganda $(1,537) .{ }^{3}$ In the conjoint experiment, the respondent is presented with a pair of hypothetical programs that their office could potentially undertake, along with the prompt, 'Below, you will see a comparison of two hypothetical programs, projects, or initiatives that could be undertaken at a government institution like yours. Please consider the information we provide about these two programs and then answer some questions comparing them.' The two hypothetical programs differ along the dimensions described in Table 1 as well as a number of other dimensions including program type, management structures and political oversight. ${ }^{4}$ In line with the above theory, we see the three treatments - visibility, transparency, collaboration - in our experiment as information treatments, which we argue facilitate greater accountability.

Table 1: Accountability Treatments and Hypotheses

\begin{tabular}{lllll}
\hline $\begin{array}{l}\text { Program } \\
\text { Dimension }\end{array}$ & Treatment A & Treatment B & Treatment C & \multicolumn{1}{c}{$\begin{array}{l}\text { Hypothesised } \\
\text { Effect on } \\
\text { Success }\end{array}$} \\
\hline Visibility & $\begin{array}{l}\text { Outputs clear and visible } \\
\text { to the public }\end{array}$ & $\begin{array}{l}\text { Outputs not visible to the } \\
\text { public }\end{array}$ & Positive \\
\hline Transparency & $\begin{array}{l}\text { Program progress will be } \\
\text { communicated regularly } \\
\text { to the public }\end{array}$ & $\begin{array}{l}\text { Program progress will be } \\
\text { communicated occasion- } \\
\text { ally to the public }\end{array}$ & $\begin{array}{l}\text { Program progress will not } \\
\text { be communicated to the } \\
\text { public }\end{array}$ & Positive \\
\hline Collaboration & $\begin{array}{l}\text { Collaboration with civil } \\
\text { society groups }\end{array}$ & $\begin{array}{l}\text { No collaboration with } \\
\text { civil society groups }\end{array}$ & & Positive \\
\hline
\end{tabular}

After examining the two hypothetical programs, the respondent is asked questions about which of the two programs is most likely to be successful, be vulnerable to corruption by high and low level officials, and reach those in need. The exact wording of these questions is as follows:

- Q1 Which of these programs is more likely to have immediate success?

\footnotetext{
3 The surveys were conducted from March through August 2017.

${ }^{4} \mathrm{~A}$ full list of the program dimensions is provided in the appendix. The selection of dimensions was guided by the literature as well as discussions with public sector program stakeholders in the three countries.
} 
- Q2 Which of these programs would be more vulnerable to issues of corruption among low-level officials?

- Q3 Which of these programs would be more vulnerable to issues of corruption among high-level officials?

- Q4 Which program do you think would be most effective in that it would provide assistance to those most in need?

The strength of the conjoint experiment approach is that it enables the researcher to learn about the perceptions of a particular subject pool (in this case, bureaucrats in the three countries) under different program conditions while also reducing social desirability bias and bias driven by context-specific details (Hainmueller, Hopkins and Yamamoto, 2013; Hainmueller, Hangartner and Yamamoto, 2015; Carlson, 2015). Further, the conjoint experiment facilitates a test of the comparative effects of different dimensions, revealing not only whether a particular dimension affects an outcome, but its comparative weight relative to other dimensions. This information, in turn, is useful for shaping policies around the strongest success drivers.

Ultimately, our approach can only definitively measure perceptions of program success. However, bureaucrats' perceptions may reflect actual success because bureaucrats are closely involved in the day-to-day implementation of programs and are thus likely to have important knowledge about the characteristics of the most successful public sector programs. With survey respondents across 140 different institutions in the three countries (48 in Ghana, 57 in Malawi and 35 in Uganda), we are likely to gain a more complete assessment of the perceived determinants of program performance than studies focusing on selected outcomes of a particular program.

Moreover, understanding bureaucrats' perceptions about the determinants of successful programs may be important in its own right. Bureaucrats are more likely to perform well when they see themselves as part of effective or prestigious organisations (Grindle, 1997), when they feel they can achieve missions and goals (Wilson, 1989; 
Franco, Bennett and Kanfer, 2002), or when they feel supported externally (Stazyk and Goerdel, 2010). The effectiveness of the organisation in successfully implementing programs shapes organisational cultures (Lewis et al., 2003) and the potential development of 'pockets of efficiency' (Leonard, 2010). As Rainey and Steinbauer (1999) explain, "where members of the agency perceive that task activities and accomplishments contribute to mission accomplishment," bureaucrats will be more likely to provide a "worthwhile and valuable public service" $(1999,26)$.

\subsection{Country Selection}

Ghana, Malawi and Uganda are, in many ways, representative of a broad swath of countries in Africa and throughout the developing world. The variation across these contexts suggests that if we find consistent drivers of success in all three contexts, these drivers of success are likely to generalise to public sector programs across similar contexts.

Since the conjoint experiment was part of a larger study on corruption, case selection was based largely on the desire to acquire data from countries with varying levels of corruption. In the past five years, Ghana's score on Transparency International's Corruption Perceptions Index (CPI) has ranged from 43-48 (on a scale of 0-100 where 100 represents the lowest levels of corruption), Malawi's has ranged from 31-37 and Uganda's from 25-29. The inclusion of multiple countries in the study enables us to qualitatively gauge the relative generalisability of observed relationships and to suggest the factors that may enhance or diminish program success in different contexts. Together, the three cases are representative of many African countries in terms of wealth/development; the size of the government and civil service; and levels of democracy.

In terms of wealth, according to the World Bank, Ghana's GDP per capita in 2017 was $\$ 1,614$, which is more than twice that of Uganda's (\$604) and five times that of Malawi’s (\$339) GDP per capita. Nearly 70\% of Sub-Saharan African countries' GDP per capita fall in the income range represented by these three countries. 
The three countries are also representative in terms of government size. Ghana's government expenditures were equal to $26 \%$ of GDP in 2016 compared to $17.9 \%$ in Malawi, and $13.7 \%$ in Uganda. Across Africa, government expenditures account for between $12 \%$ and $26 \%$ of GDP. Additionally, looking at wages as a percent of government expenditure suggests that Ghana's public sector is the largest (29\%) followed by Malawi (18\%) and then Uganda (12\%) (World Bank, 2017).

Finally, sub-Saharan African countries vary greatly in the strength (or existence) of their democracies, and our three cases represent this variation as well. Ghana is typically classified as one of the most institutionalised democracies on the continent. Malawi is seen as a weaker democracy that enjoys relatively free and fair elections although only party switching and death have lead to a peaceful transfer of executive power. In contrast, Uganda is a dominant regime that has authoritarian tendencies and has never seen a peaceful transfer of power. Ghana and Malawi also consistently outrank Uganda on indicators of the protection of rights and freedoms (see Table 4 in the appendix), and in the extent to which civil society is free from repression by the state.

\subsection{Sampling and Survey Implementation}

The survey sample is based primarily on access and convenience, with an effort to stratify the sample in a general sense across public service institutions. ${ }^{5}$ We excluded both local government bureaucrats and "street-level" bureaucrats such as teachers, nurses, doctors and bus drivers. To ensure a diverse sample, we included bureaucrats across a range of organisations, functions, levels of employment and contract-types. In Ghana and Uganda, we conducted the survey with central government bureaucrats whose primary work location is in the capital city. The sampling strategy differed to some extent in Malawi, where the Government of Malawi has been pushing for administrative and fiscal decentralisation, the

\footnotetext{
5 There are significant logistical challenges involved in obtaining a random sample of bureaucrats in African countries, many of which have an uncertain and ever-changing population of bureaucrats.
} 
sample deliberately included a subset of individuals (approximately 500) in institutions and ministries that have been decentralised and a subset of individuals (approximately 1000) that remain in the centralised institutions.

Despite the difference in sampling methods across contexts, the samples are generally quite similar. From Table 2, we can see that the average age (ranging from 3740), average years in the public service (roughly 11 years), and percent managers (ranging from 11-14) in each country's sample are roughly the same. Unsurprisingly, the Malawi sample is less educated and more male than the other two (with Ghana being the most educated). Given Malawi's lower level of development and low female employment rates in the formal sector, these differences are expected. In Malawi, we surveyed substantially more supporters of the ruling party, which is inevitable because party switching to the ruling party is commonplace in Malawi. Finally, salary distributions are relatively similar across the three countries.

Table 2: Conjoint Experiment Sample Demographics

\begin{tabular}{llllc}
\hline & \multicolumn{1}{c}{ Ghana } & Malawi & \multicolumn{1}{c}{ Uganda } & Pooled \\
\hline Number of respondents & 1096 & 864 & 495 & 2455 \\
\% Female & 48.1 & 20.7 & 44.4 & 37.7 \\
Average Age & 38.3 & 40.1 & 37.3 & 38.7 \\
\% Bachelors degree or higher & 80.0 & 35.5 & 71.0 & 68.0 \\
Average Years in public service & 11.1 & 11.4 & 10.7 & 11.17 \\
\% Management* & 11.4 & 13.6 & 13.5 & 12.6 \\
\% Ruling party supporter & 14.8 & 34.0 & 19.3 & 15.7 \\
Median income bracket & $\$ 108-\$ 323$ & \$139-\$278 & \$135-\$270 \\
\hline *Based on a question asking if managing other bureaucrats is main responsibility.
\end{tabular}

Prior to the experiment, the survey included questions regarding work experience, views toward public service, and attitudes/experiences with corruption and favoritism. Because the survey included a number of experimental elements that were not possible to include in every survey, the conjoint experiment was randomly assigned to a portion of respondents in each country - two-thirds in Ghana and Malawi and one-third in Uganda. The resulting sample sizes are as follows: 1,096 in Ghana, 864 in Malawi, and 495 in 
Uganda. Respondents evaluated two successive pairs of hypothetical programs, resulting in two sets of outcome questions for each respondent. ${ }^{6}$

\subsection{Empirical Analysis}

Our dependent variable is an index measuring program success. We construct the index using principal components aggregating responses to the four questions presented above. ${ }^{7}$ With a dataset at the level of the respondent-program pair, we use OLS to regress the success index on the full set of eight program dimensions randomised in the conjoint experiment and presented in in the appendix. We conduct a pooled analysis with data from all three countries followed by an analysis separated by country. The pooled analysis includes country fixed effects, fixed effects for respondents' institutions (i.e., the ministry or agency in which they are employed), and robust standard errors clustered at the respondent level. ${ }^{8}$ In a second set of analyses, we include interaction terms in the base models to investigate the conditional effects of visibility, transparency and collaboration.

\section{Results}

As described in the previous section, our base models investigate the independent effects of visibility, transparency, and collaboration on the success index across the three countries. Figure 1 shows results for the pooled sample including all respondents from all three countries who participated in this experiment. For each program attribute, the baseline category shows a coefficient of zero. For example, "not visible" is the baseline category in the visibility dimension such that the estimated effects of a program with visible outputs are measured in

\footnotetext{
6 To ensure that variation in sample size is not affecting our results, the appendix includes Figure 9 where we test whether the country-specific results hold when we use bootstrapping estimations to restrict the sample size for Ghana and Malawi to match that of the smaller sample in Uganda. The cross-country results are basically the same.

7 Before aggregating, we reverse the scale of the corruption questions such that, for all four questions, higher values indicate more success.

${ }^{8} \mathrm{We}$ also investigate potential differences for subgroups divided by respondent characteristics such as gender, position type and level of education. Those results are displayed in Table 5 in the appendix.
} 
reference to a program with outputs that are not visible. In all models reported, the unit of analysis is the respondent-program pair. $^{9}$

The results depicted in Figure 1 clearly indicate that bureaucrats associate all three informational mechanisms - visibility, transparency and collaboration - with a higher likelihood of program success. Visibility appears to be the strongest predictor of success with slightly higher estimates than the other attributes, though all have strongly positive and statistically significant effects on success index ratings. As is evident from Figures 5 8 in the appendix, respondents perceive having visible program outputs, updates on program progress, and collaboration with civil society as contributing to positive outcomes across all four success indicators including the effectiveness of the program and the reduction of corruption in program implementation. Moreover, the results hold across a large number of subgroups tested, the results of which are provided in Table 5 in the appendix.

Figure 1: Country Pooled Results

\footnotetext{
${ }^{9}$ Given that each respondent participated in two rounds of the experiment and evaluated two pairs of programs, each respondent produces four observations in the analysis.
} 


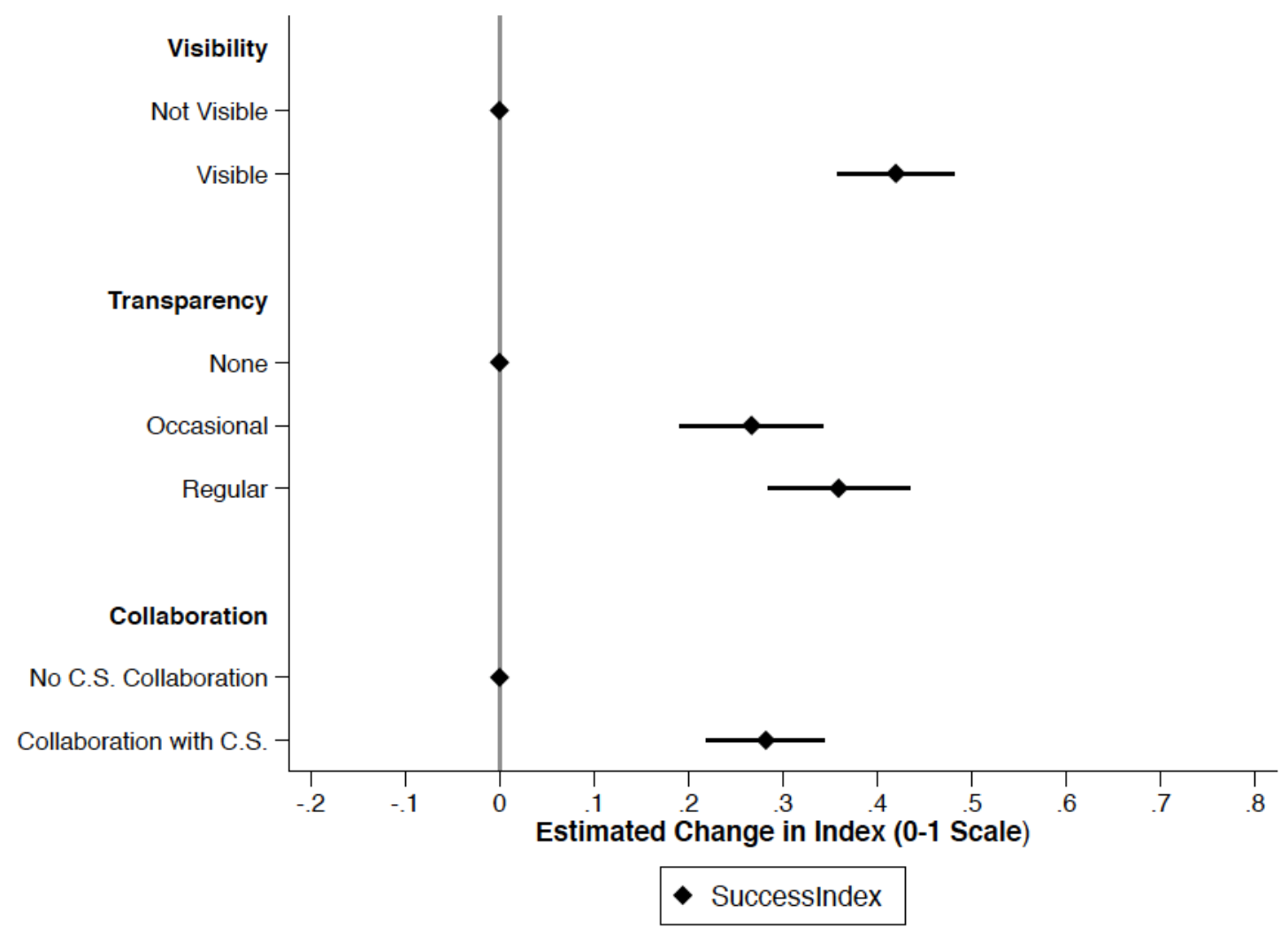

Figure 2 displays results broken down by country. These results provide some nuance to our pooled findings. While the effects of visibility remain positive and statistically significant across all countries, these effects are significantly weaker in Malawi than in Ghana and Uganda. In most cases, respondents also believe transparency has a positive influence on program success, though the results for transparency are more sensitive to both country context and whether communication about the program is "occasional" or "regular." Relative to more frequent communication about program implementation, occasional updates are less likely to bring about program success, particularly in Ghana and Malawi. Of the three information treatments, the effects of civil society collaboration on success are the most consistent across the three countries. This consistency, and the strength of the result in Uganda, is noteworthy given that the Ugandan civil society environment is considerably more repressive than that of Ghana or Malawi (See Table 4 in the appendix). 
Overall, both the pooled and country-specific models provide strong support for the idea that programs that greater information to citizens have a greater likelihood of success in terms of effectiveness, efficiency and equity likely because such information increased accountability. While there is some variation evident across countries, an issue we discuss in greater detail below, the results make clear that bureaucrats perceive the potential for social accountability in any of these three forms as a positive force for public sector programs. The strong perceived effects of visibility and the highly consistent effects of civil society collaboration are particularly striking.

As discussed above, it is increasingly common to view visibility, transparency, and collaboration as mutually supportive of program success both in terms of program effectiveness (Fox, 2015) and control of corruption (Cucciniello, Porumbescu and Grimmelikhuijsen, 2017). We test this assertion by adding interaction terms to the analysis. If respondents view visibility, transparency and collaboration as working in tandem to promote success, we should see stronger effects when these attributes are interacted with each other, meaning that they see greater likelihood of success among hypothetical programs that contain two or more of these attributes. Figure 10 in the appendix presents the results from four interaction models that include variables representing all possible two-way and three-way interactions of the three treatments. The results of these models clearly indicate that none of the interaction terms are significant predictors of program success, meaning that respondents were not likely to see the necessity of having two or more informationenhancing attributes at the same time.

Figure 2: Country Specific Results 


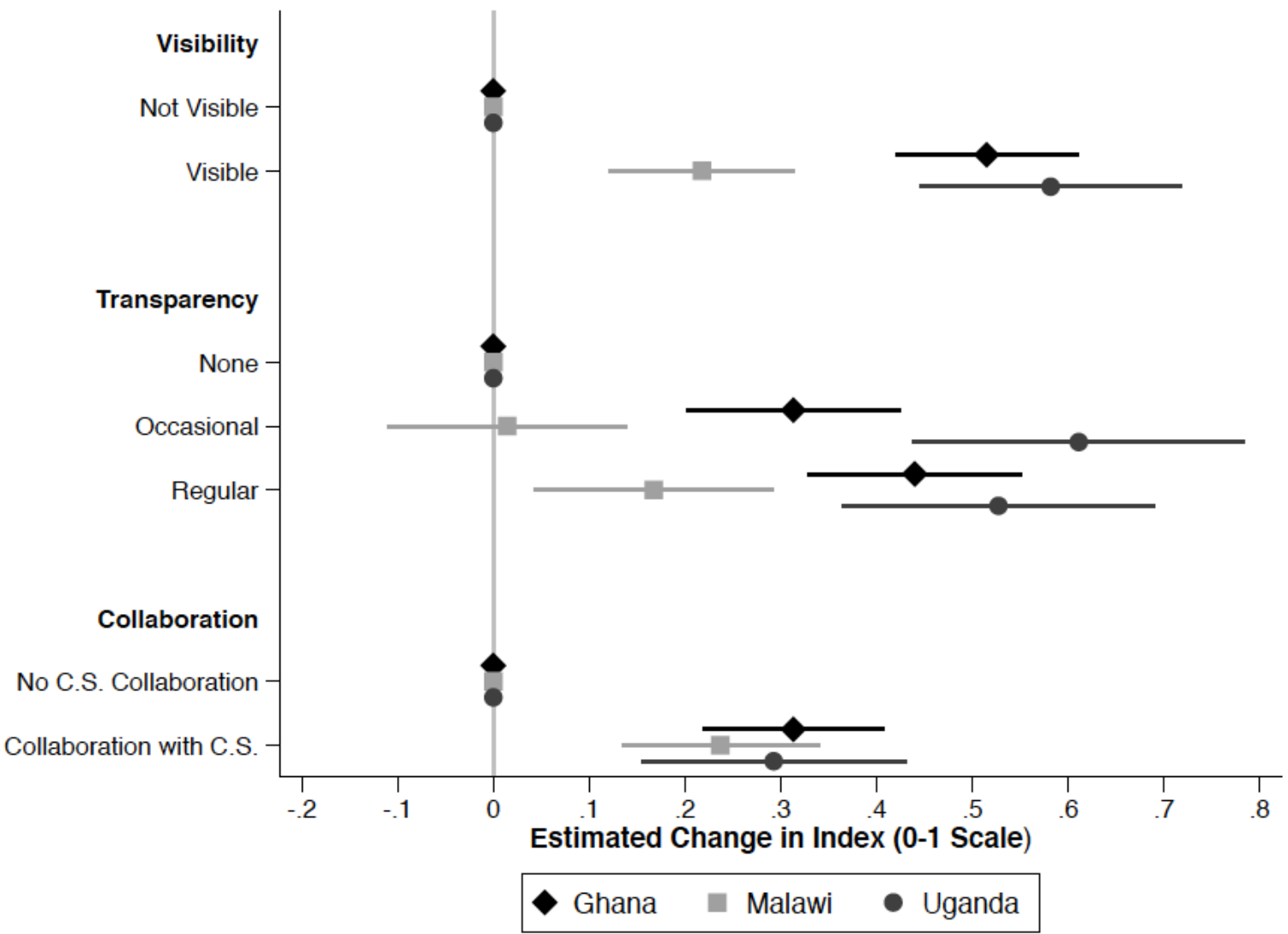

\section{Discussion \& Conclusion}

This study contributes to questions about the importance of social accountability in the success of public sector programs in the developing world. Specifically, we examine whether programs that supply information to citizens and/or civil society groups, and therefore opportunities for monitoring and accountability, are perceived by bureaucrats to be more or less likely succeed. We do so by performing a conjoint experiment with bureaucrats those most closely involved in the day-to-day implementation of programs - that randomly assigns accountability-facilitating attributes to hypothetical public sector programs. While this study only measures perceived success, the perceptions of those with intimate knowledge of government programs are important to understanding what promotes program success. Future studies should build on these findings by 1) measuring perceived 
success among politicians and citizens; 2) measuring the actual social accountability characteristics programs in order to estimate their effects on success; and 3) examining which social accountability mechanisms are most (or least) immune to elite capture.

We find that all the three program design attributes that facilitate accountability program visibility, transparency in program progress, and collaboration with outside groups - significantly increase the perceived likelihood of public sector program success. Program visibility, whereby citizens can observe the outputs of public sector programs in their dayto-day lives, is perceived as the strongest driver of program success. Transparency, particularly in the form of regular reports on program progress, is also a significant predictor of perceived program success, but the effects are in some cases smaller than they are for visibility. Among the three mechanisms of accountability explored here, collaboration with civil society has the most consistent positive effects on program success, as perceived by the bureaucrats in our study. The consistency of this latter finding is particularly striking given their varied civil society environments across the three countries. Together, these findings indicate that bureaucrats unequivocally perceive information sharing as contributing to - rather than detracting from - program success. Another implication of our findings relates to the bureaucrats themselves. While bureaucrats are known to resist social accountability interventions for any number of reasons (Wirtz et al., 2015; Bauhr and Nasiritousi, 2012; Pasquier and Villeneuve, 2007), our findings suggest they nonetheless see them as positively linked to program success.

The country-specific analyses reveal that the findings are generally consistent in Ghana and Uganda, but the pattern deviates to some extent in Malawi, where the effects of transparency and visibility are somewhat weaker and where the effect of supplying occasional transparency is indistinguishable from zero. With only three countries in the sample, it is impossible for us to meaningfully test exactly what is driving this difference. We posit two possible explanations for this deviation. First, the differences in the sample of bureaucrats surveyed may have produced different views about the importance of transparency. For example, in Malawi, the greater number of ruling party supporters, the lower 
average levels of education and the inclusion of bureaucrats working in decentralised agencies may produce different views about the importance of these information treatments related to social accountability. Second, we note that Malawi is a highly aid-dependent country, and it may be experiencing "accountability fatigue," whereby transparency and visibility could have lost some of their appeal in the wake of many attempts to address corruption issues and improve public sector effectiveness.

In fact, this latter point about Malawi suggests an important caveat about our findings. It is possible our results are capturing a form of social desirability bias, in that the bureaucrats in our study have likely been indoctrinated - especially by the international aid community - to believe that transparency, visibility, and collaboration with civil society should lead to program success, and so they report that it does in our conjoint experiment. If this is the case, the perceived effects of transparency may be weaker in Malawi because more individuals were surveyed outside of the capital, where they may be less exposed to this indoctrination, or may be less accustomed to interactions with international aid actors such as DFID. Parsing a realworld connection between our information treatments and program success from social desirability bias is an avenue for future research.

The findings also speak to debates about whether visibility or transparency alone are sufficient to improve program outcomes, or whether their potential impacts are contingent on the mobilisation potential of outside groups. We find that, contrary to a number of recent studies, interacting visibility, transparency and collaboration in different ways derives no significant advantages in terms of the perceived likelihood of program success. This finding suggests that bureaucrats see each of the accountability-enhancing dimensions working independently to affect program success. In turn, this implies that these treatments are neither substitutes nor complements for each other; adding just one of these attributes to a program, even in the absence of others, could, according to bureaucrats, yield some benefit. For example, transparency does not necessarily have to be paired with civil society collaboration in order to increase perceived program success, and it may be worth cultivating even where civil society is already strong. 
These findings have important practical and policy implications. They suggest that, in the African contexts studied, the possibility of successful program implementation could be enhanced by incorporating opportunities for information sharing and social accountability into program design. Managers may look for ways to increase the visibility of their programs (i.e., press releases of program initiation), set requirements for frequent public updates on program progress (i.e., monthly progress reports that are released to the media and civil society organisations), and build in opportunities for civil society groups to collaborate (i.e., at the development and implementation phases). Even if some of these

options are not possible, including just one of these interventions could significantly increase the likelihood of success, at least according to the bureaucrats in our study who are closely involved in program implementation. Finally, changing perceptions of the likelihood of program success may itself serve as a self-fulfilling prophecy as employees become more motivated to work on programs they believe would make concrete difference in their communities or countries.

\section{References}

Abers, R. (2000) Inventing Local Democracy: Grassroots Politics in Brazil. Boulder, CO: Lynne Rienner.

Ackerman, J. M. (2005, March 1). Social Accountability in the Public Sector: A Conceptual Discussion (Paper No. 82). The World Bank. Retrieved http://documents.worldbank.org/curated/en/514581468134386783/pdf/357330Ackerman.pdf. 
Andrews, M. (2013). The Limits of Institutional Reform in Development: Changing Rules for Realistic Solutions. Cambridge, United Kingdom: Cambridge University Press.

Andrews, M., Woolcock, M., \& Pritchett, L. (2017). Building State Capability: Evidence, Analysis, Action. Oxford, United Kingdom: Oxford University Press.

Baccarini, D. (1999). The Logical Framework Method for Defining Project Success. Project Management Journal 30(4):25-32. doi:10.1177/875697289903000405.Baiocchi, G.(2005). Militants and Citizens: The Politics of Participatory Budgeting in Porto Alegre. Redwood City, CA: Stanford University Press.

Baker, B., Murphy, D., \& Fisher, D. (1997). Factors Affecting Project Success. In D. I. Cleland \& W. R. King (Eds.), Project Management Handbook (2nd ed., pp. 902-919). New York, NY: Van Nostrand Reinhold. doi:10.1002/9780470172353.ch35.

Barma, N. H., Huybens, E., Viñuela, L. (2014). Institutions Taking Root: Building State Capacity in Challenging Contexts. Washington, DC: World Bank Publications.

Batley, R. \& Mcloughlin, C. (2015). The Politics of Public Services: a Service Characteristics Approach. World Development 74:275-285. doi:10.1016/j.worlddev.2015.05.018.

Batley, R. \& Harris, D. (2014). Analysing the Politics of Public Services: A Service Characteristics Approach. Overseas Development Institute. Retrieved https://www.odi.org/sites/odi.org.uk/files/odi-assets/publications-opinion-files/8913.pdf.

Batley, R., McCourt, W., \& Mcloughlin, C. (2012). The Politics and Governance of Public Services in Developing Countries. Public Management Review 14:131-144. doi:10.1080/14719037.2012.657840.

Bauhr, M. \& Grimes, M. (2014). Indignation or Resignation: The Implications of Transparency for Societal Accountability. Governance 27:291-320. doi:10.1111/gove.12033 
Bauhr, M. \& Nasiritousi, N. (2012). Resisting Transparency: Corruption, Legitimacy, and the Quality of Global Environmental Policies. Global Environmental Policies, 12(4):9-29. doi:10.1162/GLEP_a_00137.

Berliner, D. (2014). The Political Origins of Transparency. Journal of Politics 76:479-491. doi:10.1017/S0022381613001412

Besley, T.(2006). Principled Agents?: The Political Economy of Good Government. Oxford, United Kingdom: Oxford University Press.

Besley, T. \& Ghatak, M. (2003). Incentives, Choice, and Accountability in the Provision of Public services. Oxford Review of Economic Policy 19:235-249. doi:10.1093/oxrep/19.2.235.

Brass, J. (2014). Blurring the Boundaries: NGOs, the State, and Service Provision in Kenya. In M. Cammett and L. Maclean (Eds.) The Politics of Nonstate Social Welfare (pp. 99-109). Ithaca, NY: Cornell University Press, pp. 99-109.

Brett, E.A. (2003). Participation and Accountability in Development Management. Journal of Development Studies 40(2):1-29. doi:10.1080/00220380412331293747.

Brinkerhoff, D. W. (1999). State-Civil Society Networks for Policy Implementation in Developing Countries. Policy Studies Review 16:124-147. doi:10.1111/j.15411338.1999.tb00844.x.

Brinkerhoff, D. W. \& Brinkerhoff, J. M. (2015). Public Sector Management Reform in Developing Countries: Perspectives Beyond NPM Orthodoxy.” Public Administration and Development 35:222-237. doi:10.1002/pad.1739.

Brockmyer, B. \& Fox, J. (2015, September). Assessing the Evidence: The Effectiveness and Impact of Public Governance-Oriented Multi-Stakeholder Initiatives (Report). Transparency \& Accountability Initiative. doi:10.2139/ssrn.2693608. 
Bukenya, B. (2018). Are Service-Delivery NGOs Building State Capacity in the Global South? Experiences from HIV/AIDS Programmes in Rural Uganda. Development Policy Review 36:O378-O399. doi:10.1111/dpr.12240.

Cameron, W. (2004). "Public Accountability: Effectiveness, Equity, Ethics." Australian Journal of Public Administration 63(4):59-67. doi:10.1111/j.1467-8500.2004.00402.x.

Carlitz, R. (2010, October). Annex 2, Budget Processes: Review of Impact and Effectiveness of Transparency and Accountability Initiatives. Institute of Development Studies. Retrieved https://assets.publishing.service.gov.uk/media/57a08b22ed915d3cfd000b5e/60827Annex2BudgetProcessesCarlitzFinal280ct2010_1_.pdf.

Carlson, E. (2015). Ethnic Voting and Accountability in Africa: A Choice Experiment in Uganda. World Politics 67:353-385. doi:10.1017/S0043887115000015.

Chene, M. (2011). Good Practice in Strengthening Transparency, Participation, Aaccountability and Integrity. (U4 Expert Answer No. 274). Transparency International. Retrieved https://www.u4.no/publications/good-practice-in-strengthening-transparencyparticipation-accountability-and-integrity.pdf.

Cucciniello, M., Porumbescu, G. A., \& and Grimmelikhuijsen, S. (2017). 25 Years of Transparency Research: Evidence and Future Directions. Public Administration Review 77:32-44. doi:10.1111/puar.12685.

Deininger, K. \& Mpuga, P. (2005). Does Greater Accountability Improve the Quality of Public Service Delivery? Evidence from Uganda. World Development 33:171-191. doi:10.1016/j.worlddev.2004.09.002.

Easterly, W. (2006). The White Man's Burden: Why the West's Efforts to Aid the Rest Have Done So Much Ill and So Little Good. New York, NY: Penguin.

Ebrahim, A. (2003). Accountability in Practice: Mechanisms for NGOs. World 
Development 31:813-829. doi:10.1016/S0305-750X(03)00014-7.

Florini, A. (2007).The Right to Know: Transparency for an Open World. . New York, NY: Columbia University Press.

Fox, J. (2007). The Uncertain Relationship between Transparency and Accountability. Development in Practice 17:663-671. Retrieved https://www.jstor.org/stable/25548267.

Fox, J. (2016, December). Scaling Accountability through Vertically Integrated Civil Society Policy Monitoring and Advocacy. (Working Paper). Institute of Development Studies. Retrieved https://accountabilityresearch.org/wpcontent/uploads/2017/08/ScalingAccountability_Online4.pdf.

Fox, J. A. (2015). Social Accountability: What Does the Evidence Really Say? World Development 72:346-361. doi:10.1016/j.worlddev.2015.03.011.

Fox, J. \& Halloran, B. (2016). Civil Society Policy Monitoring and Advocacy Strategies. (Report from International Workshop June 18-20, 2015, Washington, DC). Transparency \& Accountability Initiative. Retrieved https://jonathanfoxucsc.files.wordpress.com/2011/11/fox_halloran_eds_connecting-the-dotsfor-accountability.pdf.

Fox, J. \& Aceron, J. (2016). Doing Accountability Differe ntly: A Proposal for the Vertical Integration of Civil Society Monitoring and Advocacy. U4 2016:4. Retrieved https://www.u4.no/publications/doing-accountability-differently-a-proposal-for-the-verticalintegration-of-civil-society-monitoring-and-advocacy.pdf.

Franco, L. M., Bennett, S., \& Kanfer, R. (2002). Health Sector Reform and Public Sector Health Worker Motivation: a Conceptual Framework. Social Science \& Medicine 54:12551266. doi:10.1016/S0277-9536(01)00094-6.

Fritz, V., Levy, B., \& Ort, R. (2014). Problem-Driven Political Economy Analysis: The World Bank's Experience. Washingto n, DC: The World Bank.

Gazley, B. \& Brudney, J. L. (2007). The Purpose (and Perils) of Government-Nonprofit 
Partnership. Nonprofit and Voluntary Sector Quarterly 36: 389-415. doi:10.1177/0899764006295997.

Golden, M. \& Min, B. (2013). Distributive Politics around the World. Annual Review of Political Science 16:73-99. doi:10.1146/annurev-polisci-052209-121553.

Grimes, M. (2013). The Contingencies of Societal Accountability: Examining the Link between Civil Society and Good Government. Studies in Comparative International Development 48:380-402. doi:10.1007/s12116-012-9126-3.

Grindle, M. S. (1997). Divergent Cultures? When Public Organizations Perform Well in Developing Countries.” World Development 25:481-495. doi:10.1016/S0305750X(96)00123-4.

Grindle, M. S. (2004). Good Enough Governance: Poverty Reduction and Reform in Developing Countries. Governance 17:525-548. doi:10.1111/j.0952-1895.2004.00256.x.

Grindle, M. S. (2017). Good Governance, RIP: A Critique and an Alternative. Governance 30:1722. doi:10.1111/gove.12223.

Gyimah-Boadi, E., ed (2004). Democratic Reform in Africa: The Quality of Progress. Boulder, CO: Lynne Rienner Publishers.

Hainmueller, J., Hopkins, D. J., \& Yamamoto, T. (2013). Causal Inference in Conjoint Analysis: Understanding Multidimensional Choices via Stated Preference Experiments. Political Analysis 22:1-30. doi:10.1093/pan/mpt024.

Hainmueller, J., Hangartner, D ., \& Yamamoto, T. (2015). Validating Vignette and Conjoint Survey Experiments Against Real-World Behavior. Proceedings of the National Academy of Sciences 112:2395-2400. doi:10.1073/pnas.1416587112. 
Haque, M. S. (2000). Significance of Accountability under the New Approach to Public Governance. International Review of Administrative Sciences 66:599-617. doi:10.1177/0020852300664004.

Hickey, S. \& King, S. (2016). Understanding Social Accountability: Politics, Power and Building New Social Contracts. Journal of Development Studies 52:1225-1240. doi:10.1080/00220388.2015.1134778.

Holland, J. (2017, June). What Works for Social Accountability? Findings from DFIDs Macro Evaluation. (Policy Briefing). Department for International Development. Retrieved https://gpsaknowledge.org/knowledge-repository/what-works-for-social-accountabilityfindings-from-dfids-macro-evaluation/.

Hossain, N. (2010). Rude Accountability: Informal Pressures on Frontline Bureaucrats in Bangladesh. Development and Change 41:907-928. doi:10.1111/j.14677660.2010.01663.x

Hydén, G.. (1983). No Shortcuts to Progress: African development Management in Perspective. Berkeley, CA: University of California Press.

Ika, L., Diallo, A., \& Thuillier, D. (2010). Project Management in the International Development Industry. International Journal of Managing Projects in Business 3:61-93. doi:10.1108/17538371011014035.

Joshi, A. (2017). Legal Empowerment and Social Accountability: Complementary Strategies Toward Rights-based Development in Health? World Development 99:160-172. doi:10.1016/j.worlddev.2017.07.008.

Keck, M. E. \&Sikkink, K. (1998). Activists Beyond Borders: Advocacy networks in international politics. Ithaca, NY: Cornell University Press.

Kilby, P. (2006). Accountability for Empowerment: Dilemmas Facing NonGovernmental Organizations. World Development 34:951-963. 
doi:10.1016/j.worlddev.2005.11.009.

Leonard, D. K. (2010). "Pockets of Effective Agencies in Weak Governance States: Where Are They Likely and Why Does it Matter?" Public Administration and Development 30:91-101. doi: 10.1002/pad.565.

Levy, B. (2014). Working with the Grain: Integrating Governance and Growth in Development Strategies. Oxford, United Kingdom: Oxford University Press.

Lewis, D., Bebbington, A. J., Batterbury, S. P. J., Shah, A., Olson, E., Siddiqi, M. S., \& Duvall, S. (2003). "Practice, Power and Meaning: Frameworks for Studying Organizational Culture in Multi-Agency Rural Development Projects." Journal of International Development: The Journal of the Development Studies Association 15:541-557. doi:10.1002/jid.1004.

Lewis, P. (1992). "Political Transition and the Dilemma of Civil Society in Africa" in P. Lewis (Ed.), Africa: Dilemmas of Development and Change (pp. 137-158). Abingdon-on-Thames, United Kingdom: Routledge.

Lim, C. \& Mohamed, M. (1999). Criteria of Project Success: An Explanatory ReExamination. International Journal of Porject Management 17:243-248. doi:10.1016/S0263-7863(98)00040-4.

Lindberg, S. I., Luehrmann, A., \& Mechkova, V. (2017). From De-jure to De-facto: Mapping Dimensions and Sequences of Accountability. (Background Paper to World Development Report). The World Bank. Retrieved http://documents.worldbank.org/curated/en/324501487592445304/pdf/112920-WP-PUBLICWDR17BPAccountabilitypaper.pdf.

Lindstedt, C. \& Naurin, D. (2010). Transparency is Not Enough: Making Transparency Effective in Reducing Corruption. International Political Science Review 31:301- 322. doi:10.1177/0192512110377602. 
Lowi, T. J. (1964). American Business, Public Policy, Case-Studies, and Political Theory. World Politics 16:677-715. doi:10.4324/9781315125992-11.

Marin, J. M. (2016). Evidence of Citizen Engagement Impact in Promoting Good Governance and Anti-Corruption Efforts. (U4 Expert Answer No. 21). Transparency International. Retrieved https://www.u4.no/publications/evidence-of-citizen-engagementimpact-in-promoting-good-governance-and-anti-corruption-efforts.pdf.

Muchadenyika, D.. (2017). Civil Society, Social Accountability and Service Delivery in Zimbabwe. Development Policy Review 35:O178-O195. doi:10.1111/dpr.12242.

Owusu, M. (2017). Democracy without Development: The Perils of Plutocracy in Ghana. In K. A. Ninsin (Ed.) Issues in Ghana's Electoral Politics (pp. 163-184). Dakar, Senegal: Codesria.

Pasquier, M. \& Villeneuve, J. (2010). Organizational Barriers to Transparency: A Typology and Analysis of Organizational Behaviour Tending to Prevent or Restrict Access to Information. International Review of Administrative Sciences 73 (2007): 147-162. doi:10.1177/0020852307075701.

Peisakhin, L. \& Pinto, P. . (2010) Is Transparency an Effective Anti-Corruption Strategy? Evidence from a Field Experiment in India. Regulation \& Governance 4:261-280. doi:10.1111/j.1748-5991.2010.01081.x.

Rainey, H. G. and Steinbauer, P. (1999). Galloping Elephants: Developing Elements of a Theory of Effective Government Organizations. Journal of Public Administration Research and Theory 9:1-32. doi: 10.1093/oxfordjournals.jpart.a024401.

Reinikka, R. \& Svensson, J. ( 2005). Fighting Corruption to Improve Schooling: Evidence from a Newspaper Campaign in Uganda. Journal of the European Economic Association 3:259-267. doi:10.1162/jeea.2005.3.2-3.259.

Rose-Ackerman, S.. (1999). "Political corruption and democracy." Connecticut Journal of 
International Law 14:363. Retrieved

https://digitalcommons.law.yale.edu/cgi/viewcontent.cgi?article=1580\&context=fss_pape rs.

Shin, W., Kim, Y., \& Sohn, H. (2017). Do Different Implementing Partnerships Lead to Different Project Outcomes? Evidence from the World Bank Project-Level Evaluation Data. World Development 95:268-284. doi: 10.1016/j.worlddev.2017.02.033.

Stazyk, E. C. \& Goerdel, H. T. (2010). The Benefits of Bureaucracy: Public Managers' Perceptions of Political Support, Goal Ambiguity, and Organizational Effectiveness. Journal of Public Administration Research and Theory 21(4):645-672. doi:10.1093/jopart/muq047.

Stiglitz, J. (2002). Transparency in Government. In R. Islam (Ed.) The Right to Tell: The Role of Mass Media in Economic Development (pp. 27-44). Washington, DC: The World Bank.

Stokes, S. C. (2005). Perverse Accountability: A Formal Model of Machine Politics with Evidence from Argentina. American Political Science Review 99:315-325. doi:10.1017/S0003055405051683.

Stokes, S. C., Dunning, T., Nazareno, M., \& Brusco, V. (2013). Brokers, Voters, and Clientelism: The Puzzle of Distributive Politics. Cambridge, United Kingdom: Cambridge University Press.

Sugiyama, N. B. (2016). Pathways to Citizen Accountability: Brazil's Bolsa Familia. The Journal of Development Studies 52:1192-1206. doi: 10.1080/00220388.2015.1134779.

Tambulasi, R. (2009). All that Glisters is not Gold: New Public Management and Corruption in Malawi's Local Governance. Development Southern Africa 26:173-188. doi:10.1080/03768350902899447.

Tripp, A. M. (2001). The Politics of Autonomy and Cooptation in Africa: The Case of the Ugandan Women's Movement. The Journal of Modern African Studies. 39: 101-128. 
doi:10.1017/S0022278X01003548.

Verdenicci, S. \& Hough, D. (2015). People, Power, and Anti-Corruption: Demystifying Citizen-Centred Approaches. Crime, Law and Social Change 64(1):23-35. Retrieved http://sro.sussex.ac.uk/id/eprint/56890/8/CLSC\%252C_Article\%252C_20_Apr_15.pdf.

Wetterberg, A., Hertz, J., \& Brinkerhoff, D. (2018). Social accountability in frontline service delivery: Citizen engagement and provider response in four Indonesian districts. Development Policy Review 36:O564-O585. doi: 10.1111/dpr.12273.

Williams, M. (2017). The Political Economy of Unfinished Development Projects: Corruption, Clientelism, or Collective Choice? American Political Science Review 111:705723. doi:10.1017/S0003055417000351.

Wilson, J. Q. (1989). Bureaucracy: What Government Agencies Do and Why They Do It. New York, NY: Basic Books.

Wirtz, B. W., Piehler, R., Thomas, M., \& Daiser, P. (2016). Resistance of Public Personnel to Open Government: A Cognitive Theory View of Implementation Barriers towards Open Government Data. Public Management Review 18:1335-1364. doi:10.1080/14719037.2015.1103889.

World Bank. (2017). World Development Indicators. Retrieved https://datacatalog.worldbank.org/dataset/world-development-indicators.

Zadek, S. \&Radovich, S. (2006). Governing Collaborative Governance: Enhancing Development Outcomes by Improving Partnership Governance and Accountability. (Corporate Social Responsibility Initiative Working Paper No. 23). John F. Kennedy School of Government at Harvard University. Retrieved https://www.commdev.org/wpcontent/uploads/2015/06/Governing-Collaborative-Governance.pdf. 